\title{
Teaching Materials Science-Olympiad Using Educational Design Research Method
}

\author{
Syamsu Arlis \\ Department of Primary School Teacher Education \\ Universitas Negeri Padang, Indonesia \\ syamsuarlis@fip.unp.ac.id
}

\author{
Dea Stivani Suherman \\ Department of Primary School Teacher Education \\ Universitas Negeri Padang, Indonesia \\ deastivani@fip.unp.ac.id
}

\author{
Fanny Rahmatina Rahim \\ Department of Physics Education \\ Universitas Negeri Padang, Indonesia \\ fannyrahmatina@fmipa.unp.ac.id
}

\begin{abstract}
The ongoing implementation of the Olympics will have a positive impact on the implementation of the learning process. Students will have the opportunity to develop all aspects of their personality and abilities through the Olympics. Olympic material includes the ability to solve reasoning questions, the questions tested are non-routine questions with a high level of sophistication for the size of elementary school students who are not provided in teaching materials in elementary school. This means students are required to use all abilities that have been obtained at school creatively to solve science-olympiad questions. This study aims to describe how to develop teaching materials for elementary science-olympiad using the Educational Design Research (EDR) method with the Plomp model. This research is a literature review. The main data sources were obtained from books, journals, and other writings relating to science-olympiad teaching materials in elementary schools. Data collection techniques are done by identifying book information, previous research reports, journals, articles, web, or other information that serves as information for further research. This research uses descriptive analysis method. Data analysis includes decomposition of materials according to the object of research then explained and analyzed to draw conclusions.
\end{abstract}

Keywords: literature review, teaching materials, elementary science olympiad

\section{INTRODUCTION}

Education is an important word when we talk about the quality of development of a country's resources. Education in the 21 st century requires human resources who have complete competence to be able to take part in real life, one of which is the ability to innovate in learning [1]. The 21 st century is also called the knowledge age where efforts to meet the needs of life in various contexts are more knowledge based [2].

Education in Elementary Schools as the as the foundation of education will determine how the quality of further education. The main step that must be realized is how we prepare human resources with strong character and ability to be reliable in their fields. These efforts must be pursued by realizing education that is oriented to how students are able to be creative in solving problems. Therefore, the education paradigm that emphasizes the improvement of reasoning, creativity and critical thinking must be applied in every step of the future development [3]. The government carries out education quality assurance and continuous development for students who have special intelligence to achieve top achievements in the fields of knowledge, technology, art, and sports at the education in all unit level

Based on the above description, the government is making efforts to improve the quality of education by developing the National Science Olympiad at the elementary school level (OSN-SD) to motivate all stakeholders in the field of education to consolidate, coordinate and foster better, so that the achievements of school-level students basis in Indonesia can be improved.
Elementary Science Olympiad which has been pioneered since 2003 is one of the strategic platforms to realize these efforts. The ongoing implementation of the Olympics will have a positive impact on the implementation of the learning process so that it becomes more creative and innovative. In turn, students will have the opportunity to develop all aspects of their personality and abilities through creative, effective and fun learning. The elementary science olympiad is the first step for talented students who are later expected to continue to take part in the Olympics at the middle and high school levels.

The Olympic material is sourced from the elementary curriculum which applies to science subjects. Olympic material also includes the ability to solve experimental problems, reasoning, creativity and understanding of concepts through the use of teaching aids. The questions tested are non-routine questions with a high level of sophistication for the size of elementary students that are not provided in teaching materials in elementary school [4]. This means that students are required to use all abilities that have been obtained in school creatively to solve science olympiad questions. The success of students in solving non-routine problems depends on their creations and innovations in translating and planning problem solving.

\section{METHOD}

This type of research is a descriptive study, by reviewing and describing the contents of the literature in the form of books, official government documents, and 
reports on the results of previous studies. The main data source from this research will be obtained through library research, journals and other writings relating to science olympiad teaching materials in elementary schools. Data collection techniques are done by identifying relevant information from books, previous research reports, journals, articles, web, or other information related to the title of the relevant research to look for aspects that have been determined. The data in this study were carried out by means of descriptive analysis. Data analysis includes the problem description of the object of study then described and analyzed to obtain conclusions.

\section{Teaching Materials}

\section{RESULT AND DISCUSSION}

Teaching material is one of the important components in learning. Teaching materials are useful for helping educators carry out learning activities. For educators teaching material is used to direct all activities and which should be taught to students in the learning process. Whereas students will serve as guidelines that should be learned during the learning process. Teaching material is a set of subject matter that refers to the curriculum used in order to achieve predetermined competencies

Teaching material is essentially the contents of the subject or field of study to students in accordance with the curriculum it uses [5]. Teaching material is part of the learning resource. Teaching materials are all forms of materials used to assist students in carrying out learning activities. The intended material can be either written material or unwritten material. Teaching materials are all materials (both information, tools, and texts) that are arranged systematically, which displays a complete figure of the competencies that will be mastered by students and used in the learning process with the aim of planning and studying the implementation of learning [6]. Based on the explanations stated, an explanation can be taken that teaching materials are written or unwritten materials that are arranged systematically provided to students to achieve learning objectives.

Teaching materials help teachers and students in the learning process. The function of teaching materials are: 1) Guidelines for teachers who will direct all their activities in the learning process, as well as being the substance of competencies that should be taught to students. 2) Guidelines for students who will direct all their activities in the learning process, as well as being a substance of competencies that should be learned / mastered. 3) Achievement evaluation tools / mastery of learning outcomes [7].

The benefits of teaching materials developed by educators are: 1) Obtained teaching materials that are in accordance with the demands of the curriculum and in accordance with the learning needs of students. 2) No longer depends on teaching materials that are sometimes difficult to obtain. 3) Become more like an arena developed using various references. 4) Adding knowledge and experience of educators in writing. 5) Able to build effective learning communication between educators [8]. This opinion explains that many benefits are obtained if the teacher is able to develop teaching materials. Teachers and students are helped by the development of this teaching material because it is in accordance with curriculum demands that make learning more meaningful.

Teaching materials consist of various types. Types of teaching materials in the form of: printed teaching materials, including handouts, books, modules, posters, brochures, student worksheets, wall-charts, photos or drawings, and leaflets; Audio teaching materials such as cassettes, radios, vinyl records, and audio compact disks; Audio visual teaching materials such as video compact disks, films; Interactive multimedia teaching materials (interactive teaching material) such as CAI (Computer Assisted Instruction), interactive learning multimedia compact disk (CD), and WEB-based teaching materials (web-based learning materials) [9]. Based on the description it is explained that the types of teaching materials are generally divided into two, namely printed teaching materials and non-printed teaching materials.

\section{Science Olympiad}

The Olympics is a competition from various fields of interest. The Science Olympiad is an individual competition activity of elementary and secondary education students in the field of Science, which is regulated by a set of regulations within the framework of the competition system to determine the Science Olympics champions. Science olympiad is one tool to measure the success of students' mastery of the basic sciences. The Olympics organized by various parties have different objectives depending on the scope of the Olympics. The conclusion that can be drawn is a science olympiad is a competition in the field of science by elementary and middle school students to measure students' competence in the basic sciences.

The National Science Olympiad for Elementary Schools in the field of Natural Sciences aims to enable students to understand and analyze natural phenomena around us. The material displayed in the elementary school level science olympiad activities are: 1) Skills and scientific methods; 2) Classification of living things based on food, anatomy, systematic, and habitat; 3) Processes and mechanisms that occur in living things (humans, animals, plants, and microorganisms); 4) Interaction of organisms with the environment and information about endangered animals; 5) Issues, developments and general issues regarding health, environment and technology; 6) Mechanics, which include object motion, force, momentum, mechanical energy, and fluid; 7) The form of objects, which include the nature and use of solid objects, liquid objects, and gas; 8) Electricity and magnetism, which includes static electricity, dynamic electricity, magnetic properties, and electromagnetic induction; 9) Waves and Optics, which include string waves, sound, wave properties, light, electromagnetic waves, and optical devices (mirrors, lenses, and their applications); 10) Temperature and heat, which includes temperature scale, thermometer and heat conductivity; 11) Energy and its changes, which includes energy [10].

\section{Educational Design Research (EDR)}

EDR designs and develops interventions (such as learning programs, learning strategies and teaching 
materials, products and systems) as solutions to complex educational problems, also to increase knowledge of the characteristics of interventions and processes to design and develop, or alternatively design and develop educational interventions (for example, learning processes, learning environments and the like) with the aim of developing or validating theories [11].

EDR research has two objectives, namely the first, research with an approach to developing research based on solutions to complex problems in educational practice, the second is validating theories about the learning process, learning environment, and the like. In this research, EDR will be conducted with the aim of developing products as solutions [11]. The steps that must be taken in EDR research are through the preliminary research stage, the prototype stage, and the assessment stage. The preliminary research phase consists of a needs analysis consisting of front end analysis, material analysis, and student analysis. The prototype stage consists of self-evaluation, peer evaluation, expert evaluation, small group practicality test, and large group practicality test. The assessment phase consists of an effectiveness test which functions to see the effectiveness of the product being developed.

\section{CONCLUSION}

Based on the description that has been conveyed, it can be concluded that one way to overcome the problems faced in the National Science Olympiad for Elementary Schools is to develop Olympic teaching materials. Teaching material developed in the form of printed teaching materials. Science olympiad teaching materials for elementary schools that are developed must go through development procedures. The development procedure uses the EDR method with the Plomp model through three phases, namely preliminary research, prototyping phase, and assessment phase.

\section{ACKNOWLEDGMENT}

We are very grateful for Universitas Negeri Padang for providing financial assistance in this research.

\section{REFERENCES}

[1] E.Y.Wijaya, D.A.Sudjimat, A.Nyoto. Transformasi Pendidikan Abad 21 sebagai Tuntutan Pengembangan Sumber Daya Manusia di Era Global. Prosiding Seminar Nasional Pendidikan Matematika. Vol 1 Hal 263-278

[2] A.Mukhadis, Sosok Manusia Indonesia Unggul dan Berkarakter dalam Bidang Teknologi sebagai Tuntutan Hidup di Era Globalisasi. Jurnal Pendidikan Karakter. Vol 3 No 2 Hal 115-136

[3] Wiworo. 2004. Olimpiade Matematika Dan IPA Sekolah Dasar/Madrasah Ibtidaiyah. Yogyakarta: Departemen Pendidikan Nasional

[4] Muchlis, A. 2006. Buku Referensi Maju dengan Olimpiade Matematika untuk SD. Jakarta: Karya Duta Wahana

[5] N.Sudjana. 2011. Penilaian Hasil Proses Belajar Mengajar. Bandung: PT Remaja Rosdakarya.

[6] A.Prastowo. 2011. Bahan Ajar Inovatif. Jogjakarta: Diva Press.

[7] Depdiknas. 2008. Panduan Pengembangan Bahan Ajar. Jakarta : Direktorat Pembinaan SMA.

[8] Sungkowo. 2009. Panduan Penyelenggaraan Program Rintisan SMA Bertaraf Internasional. Jakarta: Depdiknas.

[9] Depdiknas. 2010. Juknis Pengembangan Bahan Ajar. Direktorat Pembinaan SMA.

[10] Wiworo. 2004. Olimpiade Matematika Dan IPA Sekolah Dasar/Madrasah Ibtidaiyah. Yogyakarta. Departemen Pendidikan Nasional

[11] Plomp, T. 2013. Educational and Training System Design. Enschede. Univercity of Twente: Netherlands 